\title{
The Core Executive: Gender, Power and Change
}

\author{
Claire Annesley and Francesca Gains \\ University of Manchester
}

\begin{abstract}
The core executive is a central focus for the study of policy change especially in Westminster-style parliamentary democracies such as the UK. This venue is recognised as the locus of power and where attention should be given for identifying and assessing the process of policy change. It is surprising, then, that studies on women's substantive representation - showing whether and how women can make a difference to politics and policy - have not examined this institution, focusing instead on parliament or women's policy agencies. We plug this gap in scholarship in suggesting that the core executive should be the key venue for examining substantive representation of women. At the same time we present the case that the core executive is a gendered institution in terms of recruitment, resource allocation, relationships and rules. We argue that this gendered disposition shapes the opportunities and constraints available to feminist actors intent on altering the gender emphasis of public policy and illustrate this empirically through a case study of the actions and successes of two feminist ministers - Harriet Harman and Patricia Hewitt. As such this article makes a contribution to mainstream core executive research, gender and politics scholarship as well as the new and feminist institutionalist literatures.
\end{abstract}

Analytical attention on understanding political power and policy change in Westminsterstyle democracies such as the UK, Australia and Canada focuses on the core executive, those elected and unelected actors operating in close networks at the apex of governmental institutions (Dunleavy and Rhodes, 1995; Peters et al., 2000; Richards, 2007; Smith, 1999). It is surprising then that studies of women's substantive representation - researching whether and how women can make a difference to politics and policy - bypass this venue, focusing instead on women in parliament (Childs, 2004) or women's policy agencies (Outshoorn and Kantola, 2007; Squires and Wickham-Jones, 2002; 2004). Moreover, existing research struggles to form a clear link between women's presence and gendered policy outcomes.

This article addresses these gaps by directing analytical and empirical attention to the core executive as the most significant venue for achieving the substantive representation of women in Westminster-style parliamentary democracies such as the UK. At the same time we question the capacity of the core executive to deliver the demands of feminist political actors. We argue that to comprehend the potential for the substantive representation of women in the core executive, it is necessary to foreground the gendered 'disposition' (Burch and Holliday, 1996) of this institutional venue, as this underpins the formal and informal processes of policy change. We suggest that this gendered disposition shapes the opportunities and constraints available to feminist actors intent on altering the gender emphasis of public policy.

Initially we critically review the existing feminist political science literature that makes claims about how women can make a difference in politics and identify a significant gap in 
the scholarship on women's substantive representation. We then make the case for a focus on the core executive as the most significant site of political power and potential for policy change in Westminster systems. This section also highlights the gendered 'disposition' of the core executive in terms of recruitment, resource allocation, relationships and rules and how this disposition structures the opportunities available to feminist actors therein to make a change to policy outcomes. We apply this conceptual framework empirically to examine the policy-making activities of two feminist actors in the Westminster core executive: Harriet Harman and Patricia Hewitt. By feminist we mean decision makers who consciously strive for more equality between men and women. Not all women will be feminist, but some men might be. We argue that Hewitt's and Harman's relative successes at gendering policy are not to do with any innate capabilities as feminist politicians but to do with the resources and relationships placed at their disposal by the gendered core executive. Hewitt's success can be explained by her richer set of resources and relationships and by subtle changes to the gendered disposition of the core executive over time.

To make our arguments we employ a range of sources. We examine the gendered disposition of the core executive drawing primarily on documentary sources - autobiographies, media and official reports - to present an original gendered interpretation of an otherwise well-researched institution. This is supplemented by data from 30 interviews conducted by the authors in 1997-9 and 2007-08 with core executive actors such as ministers, former ministers, civil servants and policy advisers. ${ }^{1}$ These interview data are then used more extensively to form our empirical argument examining the experiences of Harman and Hewitt.

The key argument we make is that the core executive is the institutional locus of power and resources required to shape public policy in Westminster-style parliamentary democracies, but that it demonstrates a clear gender bias. This gendered disposition acts as a barrier to feminist political actors intent on re-gendering public policy. At the same time, our research suggests that the core executive is a dynamic institution and that feminist interaction with the institution under New Labour has altered its gendered disposition. We conclude by arguing, firstly, that examination of core executives as the key venues for policy change is necessary to developing feminist scholarship on how women can shape policy outcomes in political systems such as the UK and, secondly, that more attention should be paid to the changing gendered dynamics of core executives in analysis of the policy process. As such, our article makes a contribution to the mainstream core executive research, gender and politics scholarship as well as the new and feminist institutionalist literatures.

\section{Gender, Power and Change: Existing Approaches}

There is a growing international scholarship that raises empirical and analytical questions around the nature of women's representation and highlights the gendered aspects of the policy-making process (Chappell, 2004; Curtin, 2008; Lovenduski, 2005; Mazur, 2002; McBride Stetson and Mazur, 1995; Waylen, 2007). The most prominent approach on how gender can make a difference to policy outcomes is the substantive representation of women argument which theorises and seeks empirical evidence for a link between the 
number of female representatives in the legislative institutions (descriptive representation of women [DRW]) and an increase in attention to women's policy concerns and outcomes (substantive representation of women [SRW]). The SRW literature has primarily focused on two venues of women's representation and action: parliament and women's policy machineries (Childs, 2004; Childs and Withey, 2004; McBride Stetson and Mazur, 1995; Outshoorn and Kantola, 2007; Squires and Wickham-Jones, 2002; 2004).

Although valuable, there are normative, analytical and empirical difficulties with the SRW argument. The initial normative assumption that women act for women is problematic. As Sarah Childs points out, female bodies might not equate with feminist minds let alone feminist actors (Childs, 2004). Moreover, it is impossible to identify a universal women's interest as these vary culturally, geographically and temporarily (Hill and Chappell, 2006; Vickers, 2006). However, we agree with Geoffrey Vickers (2006, p. 18) that women share political interests arising from their childbearing capacity and how this impacts on women's and men's relationship with formal institutions of the state. In response women may, through 'delicate and mutable alliances', adopt a 'strategic essentialism' (Hill and Chappell, 2006 , p. 2) to counter men's dominance in decision making and the marginalisation and depoliticisation of women's experiences in state discourse (Vickers 2006, pp. 17-8). In parliamentary democracies like the UK, Canada and Australia there are, for example, deeply embedded gender differences in the way in which paid and unpaid work is rewarded with huge fiscal and personal consequences for citizens. The way in which these gendered political interests and demands are recognised by political actors and how the political and policy processes respond to them is a legitimate and, we argue, under-researched area.

The principal analytical difficulty with the SRW argument is that it does not acknowledge institutionalist insights into the opportunity structures available to feminist actors. Women inclined to act for women are constrained by numerous 'personal, institutional and party political factors', particularly in parliamentary systems where there is strong party discipline, such as the UK (Mackay, 2008, p. 127). This is particularly the case in the Westminster model where policy making is dominated by the executive and policy networks (Durose and Gains, 2007). But it also applies to corporate decision-making systems such as Sweden or Germany, where decisions are traditionally agreed by social partners before they reach parliament (Annesley, 2007; Hernes, 1987). The limitations of SRW through women's policy agencies are also evident. They are frequently poorly resourced, weakly institutionalised and easily dismantled when the political landscape changes (Outshoorn and Kantola, 2007; True, 2003).

There are also empirical difficulties in linking the number of women representatives (DRW) with their ability to push through policy change (SRW) and the limits of the critical mass approach have been highlighted (Childs and Krook, 2008). As in any analysis of policy making, causality is difficult to determine and what may be described as 'backbench pressure' may not reflect the agenda-setting activity of other actors in and outside the core executive. Despite these concerns, empirical research has produced some evidence of the link between DRW and SRW but this remains on the 'margins of legislative activity' (Mackay, 2008) and says little about substantive areas of concern such as citizenship rights, economic equality and social justice. 
Some recent critiques of the SRW in parliament and women's policy agencies have come from scholars who initially advocated this approach. Karen Celis et al. (2008) highlight the shortcomings of research that asks: 'do women represent women?' and 'do women in politics make a difference?' and propose new questions such as 'who claims to act for women?' and 'where, why and how does the SRW occur?' Fiona Mackay (2008, p. 129) calls for a 'thick' conception of SRW, 'a contextualised, inter-relational, whole-system approach' to how women's policy change occurs. All agree that the focus needs to shift away from women in parliament and women's policy machineries to include other sites and political actors, increasingly referred to as 'critical actors' who might be 'male and female legislators, ministers, party members, bureaucrats and members of civil society groups' (Celis et al. 2008, p. 104). However to date SRW scholars have not researched the core executive as the important site for the SRW in the UK or other parliamentary democracies.

An emerging comparative literature on women and executives (Jalalzai, 2008) analyses the recruitment of women to the pinnacle of the executive branch - prime ministers and presidents - but ignores other female actors in the executive and the impact elite executive actors have on policy substance. Joyce Mushaben (2005) claims to identify a link between the presence of women ministers and positive policy outcomes for women in Germany by adopting the critical mass approach. However, there are analytical problems with her assumption that an increase in women ministers will automatically lead to positive outcomes for women. We do not argue that women ministers will automatically pursue a feminist policy agenda. Rather our claim is that the substantive representation of women is more likely to follow from the presence of feminist actors in the core executive.

What feminist literatures do increasingly identify, however, is the extent to which the institutional context matters. The opportunities for and constraints on women's descriptive and substantive representation relate strongly to the configuration of political institutions. To understand how SRW occurs, it is important to be clear about where the power lies in any institutional context (Chappell, 2004) as well as processes of policy change. From this institutionalist perspective we argue that in parliamentary democracies, such as the UK, the core executive is where power resides and is the most appropriate site for the substantive representation of women. The ministerial role is by definition about getting things done (Kaufman, 1997) and 'being seen to make a difference' (Bevir and Rhodes, 2006a, p. 122). We analyse the core executive here through a feminist institutionalist lens (Kenny, 2007; http://www.femfiin.com) to identify the gendered nature of the formal and informal rules that structure power and opportunities for policy change. A feminist institutionalist approach also recognises the ways in which institutions are interdependent both horizontally and vertically: formal and informal rules in one institutional setting influence outcomes in another. For example, recruitment of female ministers to the core executive is related to the (un)availability of female candidates in parliament. In addition, the formal and informal division of labour in the institution of the family impacts on the power structures in the core executive.

Our approach, then, builds on SRW scholarship which attempts to demonstrate that women in politics can make a difference to policy outcomes. We argue that it is not enough to focus on critical actors but that it is necessary to place them in their institutional context, 
highlighting that this both enables and constrains their ability to make substantive policy changes. Critical actors are enabled by operating in institutions that distribute power and resources. In the case of Westminster-style democracies this is the core executive. At the same time it is necessary to develop a clear understanding of the way the institution itself is gendered and that it interconnects with other gendered institutions, such as parliament and the family. Clearly, families comprise men and women. However, the biological reality of childbearing, as well as the dominant cultural expectation that women are the primary carers of children and elders, impacts on their capacity to operate at this level. The gendered disposition of these institutions acts as a constraint to feminist actors seeking policy change.

\section{Gender and Power in the Core Executive}

A research focus on the core executive as the key venue for understanding policy making in Westminster democracies has developed analytically and empirically since the 1990s (Dunleavy and Rhodes, 1995). This body of work argued for a reorientation away from existing static, constitutional and normative traditions, drawing instead on historical institutionalist and interpretive approaches. The core executive is defined as the 'centers of political authority which take policy decisions' and refers to 'all those organisations and procedures which coordinate central government policies, and act as final arbiters of conflict between different parts of the government machine' (Rhodes, 1995, p. 12). The core executive is the institution that provides the necessary resources for mobilising the delivery of public goods (Smith, 1999). It is the "complex web of institutions, networks and practices surrounding the prime minister, cabinet, cabinet committees and their official counterparts, less formalised ministerial "clubs" or meetings, bilateral negotiators and interdepartmental committees' (Rhodes, 1995, p. 12). Martin Burch and Ian Holliday (1996) suggest that these formal, informal and semi-formal institutions shape individuals' behaviour and the strategies and goals they pursue. Thus far attention has been devoted to understanding the institutions and processes of policy making inside government departments (Smith et al., 1993; Marsh et al., 2001), between departments and executive agencies (Gains, 2004), in cabinet committees (Burch and Holliday, 1996) and in ministers' private offices (Bevir and Rhodes, 2006a).

Except for a very small literature on the gendered aspects of the civil service both internationally (Chappell, 2004) and in the UK (Watson, 1994), there is no scholarship that looks at the gendered dimensions of the core executive. The need for such a perspective has, however, been recognised. Marsh et al. (2003, pp. 309-10) argue that British society is characterised by 'structured inequality' in terms of class, gender and ethnicity which affects institutions of politics, including in the core executive. Indeed, the formal and informal institutional rules of the core executive determine the way that resources are available to political actors and govern the way these resources are exchanged and the strategies and tactics required by actors. Burch and Holliday (1996) stress that the institutional configuration of the cabinet system is not neutral in its composition. Rather, the institutional arrangements imbue it with a certain 'disposition' causing institutions to operate in selective and partial ways which advantage some office holders and which are hard to change. The 
ability to exploit this advantage will allow certain interests and policy initiatives to prevail over others (Burch and Holliday, 1996, p. 6).

We argue, using Burch and Holliday's term, that the core executive has a gendered disposition as a consequence of years, decades and centuries of practices that traditionally excluded women. Our claim is that the core executive's gendered disposition detrimentally affects the opportunities for women to introduce gendered policy change. We develop this line of argument by discussing firstly the gendered aspects of becoming an actor in the core executive - recruitment - and therefore gaining access to the resources necessary for the exercise of power and implementation of policy change. Then we look the gendered aspects of operating in the core executive, at the networked power-dependent relationships and the formal and informal rules (norms, values and practices) that shape the behaviour and opportunities of actors.

\section{Becoming and Staying an Actor in the Core Executive}

Formal power to mobilise resources and make decisions in the core executive resides with a range of elected and non-elected actors (Burch and Holliday, 1996). Martin Smith et al. (1993) point out that most decisions are made in departments where ministers are responsible. We argue that access to these positions of power is gendered for ministers, their special advisers and bureaucrats. As Clare Short, former Secretary of State for International Development, notes, 'the conflict over women's representation and the resistance to change from those with ambition taught me how narrow is the channel of recruitment into politics' (Short, 2004, p. 41). The explanations for this unequal access to power in the core executive lie in the gendered composition of other institutions that supply the core executive, and the gendered division of caring responsibilities which militates against women achieving and maintaining power in this 'family-unfriendly' institution.

In parliamentary systems ministers are recruited from the ranks of elected MPs, ${ }^{2}$ so a high descriptive representation of women in parliament is a prerequisite for ensuring a potential supply of women to the core executive. However, the process of becoming a minister varies according to different - and also gendered - political party and core executive traditions (Curtin, 2009). From 1964 to 1990 Conservative Cabinets had only had one elected female MP - Margaret Thatcher ${ }^{3}$ - and John Major's first Cabinet was the first all-male Cabinet since 1964, something that had to be pointed out to him by the then civil service press secretary Gus O’Donnell (Hogg and Hill, 1996). In response John Major appointedVirginia Bottomley and Gillian Shephard as junior ministers to 'bring them on' (Hogg and Hill, 1996). Sarah Hogg and Jonathon Hill also note that Major's options were substantially restricted by 'the small pool of available women MPs on the Conservative benches due to family unfriendly hours and the bias of constituency selection committees' (Hogg and Hill, 1996, p. 11). As a consequence of Labour's earlier engagement with gender equality policies, Blair's first appointments to Cabinet in 1997 included four women Cabinet ministers ${ }^{4}$ (Durose and Gains, 2007). Subsequently a record number of female MPs gained ministerial posts. Despite the improvement of women's representation in parliament, women remain under-represented in the ministerial ranks. 
Just as the supply and demand of parliamentary candidates is governed by informal gendered norms about what makes a good politician (Norris and Lovenduski, 1994), so too is the process of becoming a minister and what makes a good minister (Hennessy, 1989). The key to becoming and remaining a minister, according to Gerald Kaufman's seminal guide (1997) is to get noticed, but not to be notorious. Yet female MPs are judged by different criteria than male MPs, with parliamentary sketch writers focusing on dress sense and appearance, not policy substance and political skill (Bunting, 2009; Childs, 2004; interview with journalist, 2008). Aspirant ministers also need to be loyal to the party leadership and prime minister, play the favours game and be well networked. Although female parliamentarians increased in 1997, they were not automatically on the prime minister's radar as potential ministers and Blair's political secretary 1997-2001, Sally Morgan, had to draw Blair's attention to good female MPs who would make suitable ministers (interviews with minister and policy adviser, 2007). Finally, ministers are recruited from the ranks of experienced MPs yet many female MPs elected in 1997 chose only to serve one term, citing dissatisfaction with the culture of Westminster and working hours incompatible with family life. The demands of a ministerial career are even tougher than those of an MP. Transport Secretary Ruth Kelly's resignation in 2008 to spend more time with her family was assumed to be code for political dissatisfaction yet may genuinely reflect the pressures of combining high office with a young family.

Alongside ministers in departments and Number 10 are political advisers. All three political advisers who acted as Blair's gatekeeper were women: Anji Hunter (1997-2001); Sally Morgan (1997-2001 as political secretary and 2001-5 as Director of Policy and Government Relations); and Ruth Turner (2005-7). Amanda Platell (2001) highlighted gendered comments in the media surrounding the resignation of Anji Hunter, suggesting that British politics 'is still an ugly place for women ... we still have a problem with the female adviser especially when they look like Hunter'. When Sally Morgan resigned, she cited the gruelling price to be paid on family life, something corroborated by Fiona Millar (Cherie Booth's press adviser and wife of Alistair Campbell, Blair's press officer): 'Morgan would be getting to the office at 7.30 a.m. and not leaving until 9 p.m. at night ... People don't understand how punishing the job is' (Aitkenhead, 2005). Another (male) adviser describes the pressures of the work, arguing that 'it's not possible to combine it with bringing up a family. It's an all consuming job' (Aitkenhead, 2005). Mark Bevir and R. A. W. Rhodes stress, following their analysis of ministerial diaries, that 'the pace of events is relentless and endless' (2006a, p. 124).

Long-standing good employment practices to accommodate flexible working in the wider civil service have not increased the number of the most senior female civil servants (Public Administration Committee, 2007, Q73; Watson, 1994). Sylvia Watson (1994) argued that women in the senior civil service need to behave 'like the right sort of chap' in order to achieve promotion and 'at the top there is still a powerful belief that you should be available for work at any hour in times of pressure or crisis' (Watson, 1994, p. 219). The necessity to work late is part of the 'code of ethics of the selfless civil/public servant' (Watson, 1994, p. 220) but this is a structural constraint for those with domestic responsibilities. Clare Short, discussing her private office when Secretary of State for International Development, 
considered it 'a badge of pride that I had a succession of private secretaries with small children who did get home and see them when they weren't travelling' (Short, 2004, p. 64), a situation noteworthy because of its rarity.

Although there is greater diversity in the senior civil service, the percentage of women in the senior civil service was still only 32 per cent in 2008, higher than female representation in Cabinet and parliament, but lower than in appointed public bodies (Civil Service Statistics, 2008; O’Donnell, 2006). In 2001 the government set targets to increase women's presence in the civil service through the gender equality public service agreement (Durose and Gains, 2007). The current Cabinet Secretary, Gus O'Donnell, is committed to improving diversity at the most senior levels and argues that the profile of fast-stream recruits who represent tomorrow's elite public servants - is moving away from the previous male, Oxbridge bias (O’Donnell, 2006; Public Administration Committee, 2007). O’Donnell also aims to lead by example, citing his request to leave a meeting with the prime minister to attend a school open evening (BBC, 2007).

Despite attempts to change the diversity of the senior civil service, the government missed its target of increasing the proportion of female senior civil servants to 37 per cent in both 2004 and 2008 (Civil Service Statistics, 2008; WEU, 2005, p. 29). At the time of writing, only 8 of 44 permanent secretaries are women and only 6 of these head a spending department. ${ }^{5}$ A recently retired female permanent secretary, Dame Sue Street, former head of the Department of Culture, reflected: 'I'm very disappointed that the proportion of women at the top is so small. I conclude that there is still something of a "big beast" culture in Whitehall and I think that has to be challenged' (BBC, 2007). As Bevir and Rhodes (2006a, p. 111) note, life in the ministry is still about the interactions of 'overwhelmingly middle aged, white, university educated men'. Moreover, if 'you join the private office [you] lose your private life' (Bevir and Rhodes, 2006a, p. 115).

\section{Operating in the Core Executive: Accessing Power Resources}

The institutional rules of UK government grant actors in the core executive formal roles and allocate power resources (Smith, 1999). Political resources such as authority and legitimacy are held by ministers and the prime minister. These derive from their elected status and their constitutional executive powers to make policy and command the vast departmental and core governmental infrastructure. Other organisational resources such as policy, budgetary and managerial information and expertise are held by bureaucrats in departments and agencies and increasingly by non-governmental organisations and actors. No single actor controls all the resources, and power in the core executive is derived from command over and exchange of resources and the dependency this creates between actors. For example, Clare Short describes 'battling' with the Treasury during the creation of the Department for International Development in 1997 to ensure that she, as Secretary of State for International Development, held the office of UK Governor of the World Bank, providing her with additional financial, informational and authority resources to deliver on the international development policy platform (Short, 2004).

New Labour has strengthened resources at the centre in the Prime Minister's Office, the Cabinet Office and the Treasury (Bevir and Rhodes, 2006b; Burch and Holliday, 2004). 
The Treasury under Gordon Brown became more powerful, extending its reach into the work of departments through public service agreements (Bevir and Rhodes, 2006b; James, 2004). In departments, policy advice is diverse, coming from special advisers, task forces, policy think tanks, as well as civil servants (Foster, 2001). Devolution has ceded decisionmaking responsibility to the Scottish Parliament and Welsh Assembly for delegated matters (Mackay, 2006). These changes to the formal and informal institutions of governance have altered the allocation and operation of political roles and resources within the core executive, changing power-dependent relationships between critical actors. Nevertheless, with the continuing departmental and hierarchical organisation of Whitehall and the maintenance of the doctrine of ministerial responsibility as the main source of political authority and accountability, the role played by individual ministers remains critical for matters not ceded through devolution (Bevir and Rhodes, 2006b, p. 678; Flinders, 2002) and ministers' entrepreneurship can be clearly linked to particular policy outcomes (Gains, 1999; Marsh et al., 2001). Committed ministers in departments of state have hierarchical authority and infrastructural power and the extent to which individual Cabinet ministers sign up to change is a critical factor to facilitate or block change.

We argue that the allocation of political and organisational resources in the core executive is gendered because women tend not to be allocated ministerial portfolios that wield the most power or resources. As Short stresses, greater representation of women in parliament and in Cabinet after 1997 did not automatically grant feminists access to the centre of power (Short, 2004, p. 102). In terms of the four great offices of state, Margaret Thatcher was the only female (but not feminist) prime minister (1979-90), Margaret Beckett served as Blair's Foreign Secretary (2006-7) and Jacqui Smith (a feminist) served as Home Secretary under Gordon Brown (2007-9). Some self-professed feminist ministers have headed spending ministries: Harriet Harman was Secretary of State for Social Security 1997-8; Clare Short was Secretary of State for International Development 1997-2003; and Patricia Hewitt was Secretary of State for Trade and Industry 2001-5 and Secretary of State for Health 2005-7. Other women have held significant ministerial portfolios but have not enjoyed full access to the Cabinet. When Caroline Flint resigned as Minister for Europe in 2009 she complained that Brown ran a 'two-tier government which excludes women from his inner circle' (Watt, 2009).

However women ministers are frequently given 'housekeeping' and 'organisational' roles such as Leader of the House of Commons (Margaret Beckett, 1998-2001; Harriet Harman, 2007-), Leader of the House of Lords (Baroness Jay, 1998-2001; Baroness Amos, 2003-7; Baroness Ashton 2007-8) and Chief Whip (Ann Taylor, 1998-2001 and Hilary Armstrong 2001-6). In these roles they facilitate the networks and practices necessary to exchange resources but have no resources with which to shape public policy outcomes.

New Labour created a Cabinet-ranking Minister for Women, fulfilling its opposition pledge. However, this portfolio was unpaid, held at the same time as other responsibilities and carried with it few resources (Squires and Wickham-Jones, 2002; 2004). One organisational and informational resource specifically attached to the role of Minister for Women is the Government Equalities Office (GEO) ${ }^{6}$ (formerly the Equality Office, Women and Equality Unit and initially the Women's Unit). This self-standing department is responsible 
to the Minister for Women for strategy on equality, monitoring the gender equality duty and providing empirical material for monitoring and evidence-based policy making. The current GEO is more institutionally embedded with clearer lines of responsibility than its precursor, established in 1997 as a small research office within the Department of Social Security (DSS). A key improvement in its institutional authority came under Sally Morgan's tenure as Minister for Women when the unit began reporting to a Cabinet committee on how the government's public service agreement on equality was being met across government (Durose and Gains, 2007). This linking into the formal machinery of government helped to overcome the issue identified by Mo Mowlam, former Secretary of State for Northern Ireland, when she was Opposition Spokesperson for Women's Issues:

I concluded that to have a separate women's ministry is good window dressing, good to build the morale of women, but it doesn't help get women any closer to power. I think the best model to fight for equality is to have a team of people or a unit in no. 10 so that every time the Prime Minister breathes on a policy issue the unit is there, to get decent legislation in place (Mowlem, 2002, p. 19).

Our argument is that feminists intent on pursuing gendered policy change need to hold positions that grant access to power and resources. The support of non-feminist elites will facilitate the feminisation of policy making (Mazur, 2002). However, if the key elites do not have intentions to feminise policy, then the potential for gendered policy change will be significantly constrained. How to operate as a minister is also key to realising policy change and next we examine how policy making within the core executive also reflects gendered processes and practices.

\section{Operating in the Core Executive: Network Relationships}

To get policy proposals translated into programmes of action, committed policy actors need to exchange resources with each other and with outside organisations (Marsh and Rhodes, 1992). The dependency this creates can lead to very close (functional) policy networks, insulated from outside pressures and influential in controlling which issues reach the agenda and how policy problems are perceived and should be addressed (Smith, 1993). As a former senior official put it, 'to get things done a Minister needs the budget of a big department of state plus the ear of vested interests' (interview, 2008). Within the core executive, actors operate within formal and informal process networks and trusting relationships lie at the heart of the core executive (Bevir and Rhodes, 2006a; Gains, 2004). The formal networks are key to understanding policy formation and include the system of cabinet committees that deal with the progress of business and the bilateral discussions that take place between the Treasury and spending departments to set public service targets and agree budgets (Burch and Holliday, 1996; 2004; Deakin and Parry, 2000). The Cabinet committee, to which departmental ministers reported on gender mainstreaming initiatives, embedded the work of the Women and Equality Unit into the established 'Whitehall way' of doing business, increasing its effectiveness (Veitch, 2005).

Also important are the personal links and relationships that exist between individuals within the Whitehall or Westminster village famously depicted by Hugh Heclo and Aaron Wil- 
davsky (1979). As Burch and Holliday note (1996, p. 65), 'more formal relations within government are underpinned by close informal contacts, friendships and acquaintances' and 'in all organisations, a substantial amount of business is conducted through such channels. Often, a decision can be shaped or even determined in moments before or after formal meetings, during a chat in the corridor, by telephone, or over lunch' (pp. 65-6). Bevir and Rhodes (2006a) highlight the importance of 1:1s (one to ones) and KIT (Keep in Touch) meetings as mechanisms for maintaining the departmental memory and maintaining the trusting relationships necessary for the smooth running of business.

As with the occupation of roles in the core executive and the allocation of resources, membership of these formal and informal networks is, we argue, gendered. Women may not have access to the spaces for these discussions either because they are closed fora or because family commitments prevent socialising. Watson argues that traditions of loyalty in the civil service can act as mechanisms of exclusion and her female interviewees described 'networks, social relationships and camaraderie between male civil servants which excluded them. This ranged from men acting as patrons for other men and giving them a helping hand to men passing on information in exclusively male spaces or over drinks after work' (Watson, 1994, p. 219). Indeed, one of the interviews with a former permanent secretary upon which we draw for this article had to be conducted in space at the entrance to a club that did not admit women.

The Westminster village under New Labour and the culture around the inner circle of New Labour advisers and core ministers continues to be labelled 'blokey' and 'laddish' (Bradberry, 1998; Coote, 2000; Harman, 2004). Jackie Ashley argues that New Labour has been more female friendly in its policies than its political culture (Ashley, 2004) and that there has been a 're-masculinisation' of networks under Brown (Ashley, 2008). Sir Richard Mottram, former Permanent Secretary, giving evidence to the Public Administration Committee, described a culture around special advisers that is 'very laddish and exclusive in the sense of pushing people out' (Public Administration Committee, 2009). Moreover, there is a perception in Whitehall that Brown 'has a problem with women' with a Foreign Office official saying that 'his advisers have to be male because sometimes the only way to get a decision is to follow him into the loo' (cited in Day, 2009). We argue that it can be difficult for feminist ministers to access these high-trust networks that lie at the heart of the policy process.

There is evidence, however, that several formal and informal networks became established and impacted upon the work of the Minister for Women and the women's unit. The Women's Budget Group, which lobbies on the gendered aspects of fiscal policy, is consulted by the Treasury although its impact on policy change is unclear (Himmelweit, 2005, p. 112). A network of civil servants responsible for gender mainstreaming initiatives across departments met periodically, creating an informal network familiar with the ways of Whitehall (Veitch, 2005; interview with DSS official, 1999). Other informal political networks and friendships acted as a mechanism for promoting gender issues. Feminist actors across the system were bound together by years of Labour party activism (interview with senior Labour party activist, 2007) and a number of well-connected feminist policy wonks from 
the Institute for Public Policy Research (IPPR) used their links to drive policy change (interview with senior policy adviser, 2008; Annesley, 2010).

\section{Operating Rules in the Core Executive: Tactics and Strategies}

The effectiveness of actors within the core executive depends on the tactics and strategies employed to exchange their resources within networks, given the guiding norms and practices of the core executive. At the centre of this nexus of relationships is that between minister and department. Ministers need to take charge of their brief and not accept the official's version of priorities (Kaufman, 1997). Yet to push through feminist policy change ministers are dependent upon the civil service to develop policy proposals. Constitutionally the 'neutral' civil service delivers what the minister wants. However, as Louise Chappell (2006, p. 227) argues, the norm of bureaucratic neutrality in the Westminster system of government is inherently gendered: 'despite their neutral appearance, embedded assumptions about appropriate forms of behaviour in the public service are, in fact, masculine'. Ministers seeking feminist policy change may experience resistance to reforms that depart from how things are normally done.

Resistance may not be explicit or obstructive. Barbara Castle, in describing her first encounter with her permanent secretary, Sir Andrew Cohen, mentions that he 'used to swear that he would never work for a woman' (Castle, 1993, p. 343). When the Treasury developed its winter fuel scheme giving pensioners grants towards fuel costs the initial proposal was to make the payment by household to the male head of household. A DSS official had to draw the Treasury's attention to the gendered implications and operational difficulties with this proposal, and observed: 'what bothers me is it was common sense and I think to some degree it reflects having a lot of people in high policy who are intellectually capable but maybe not having the practical experience' (interview with DSS official, 1999). In the Department for Trade and Industry (DTI), a senior official argued that generally 'there was no resistance to gender in the DTI, no pressure to make the issues go away'; the 'neutral' civil service 'played its role properly' (interview, 2008). However, the same official conceded that the DTI needed convincing with evidence from the Equal Opportunities Commission as to why gender was relevant (interview, 2008). Departments such as the DTI do not automatically know how to 'do' gender policy and the lack of experience in identifying issues as having gendered implications demonstrates in fact how gendered they are.

A second important dynamic in the core executive is between a minister and Cabinet. Departments see a strong minister as one who can win arguments and resources (Bevir and Rhodes, 2006a, p. 119; Hennessy, 1989). This combative culture is graphically explained by Hogg and Hill (1996, p. 120) in their description of the workings of the EDX expenditure committee during budget deliberations. In contrast, two feminist ministers in the second New Labour government - Estelle Morris and Tessa Jowell - consciously challenged the combative culture to cooperate over the allocation of resources in the area of funding for school sport. Jowell commented: 'for the first time ever we've put in a joint bid for these programmes which is unheard of in the rivers where the testosterone flows and success is measured by how much money you get' (Bedell, 2002). 
It is clear that the core executive remains the most significant site of power and policy change in Westminster-style democracies and should become the central focus of studies of the SRW. Yet the UK core executive has a gendered disposition in relation to its recruitment, roles, access to resources, membership of networks and tactics used by core executive actors. This is the consequence of the traditional exclusion of women and the way the institution interconnects with other institutions such as the family. It may prove harder for politicians and bureaucrats with caring responsibilities, many of whom are women, to access and operate effectively in the male domain that is the core executive. Certainly many of the comments made by women ministers who resigned from Brown's government in May and June 2009 corroborate this (Bunting, 2009).

However, the core executive is a dynamic institution (Hay and Richards, 2000). Since 1997 feminist actors have held office in greater numbers, there have been developments since Watson's 1994 analysis to improve the gendered composition of the bureaucracy and new networks of officials with mainstreaming responsibilities have been established. Despite these changes we maintain that the gendered disposition of the core executive - be it formal or informal, subtle or explicit - continues to structure the capacities of feminist actors to achieve SRW. Even if they are committed to change, and have access to ministerial resources to pursue their agenda, they still might not succeed. To illustrate this empirically, drawing on interview data with politicians, civil servants and advisers, we contrast the experiences of two feminist ministers to introduce policy change promoting gender equality.

\section{Gender and Policy Change in the Core Executive under New Labour}

The election of the Labour government in 1997 created an opportunity for gendered policy change. The campaigning of feminist actors within the party during Labour's years of opposition led to a gendered reframing of a range of policy issues, from democratic representation to employment (Lovecy, 2007; Perrigo, 1995; Russell, 2005). This redefinition of policy problems as gendered was accepted in part because of the electoral necessity of winning women's votes (Annesley and Gains, 2007, p. 10). As one New Labour policy adviser observed, 'women were a key part of the New Labour coalition' (Bright, 2005). New policy proposals were available both in the UK and internationally and there was political impetus to push through reform. The combination of a psephological imperative with feminist problematising and advocacy of policy solutions opened a sizeable window of opportunity for policy reform between the 1997 and 2005 elections.

This window of opportunity was enhanced by a 197-seat majority and the highest proportion of female MPs ever seen in the UK parliament. Among these female MPs were a significant number of committed feminists, some of whom were awarded ministerial posts - Harriet Harman, Patricia Hewitt, Margaret Hodge, Beverley Hughes, Clare Short and Tessa Jowell (Sieghart, 2001; interviews with ministers, 2007) - and so we might anticipate attempts at gendered policy change. There is indeed evidence of a significant 'engendering' of policy since 1997 (Annesley et al., 2007). Although no research has established a link between core executive actors and gender policy outcomes, insider accounts have suggested that gendered policy developments were seen where departments were headed by women 
or where women ministers had an interest in gender mainstreaming (Veitch, 2005). However, we argue that having a committed feminist actor in charge of a department is not sufficient to implement gendered policy. We examine the contributions of two committed feminist ministers - Harriet Harman and Patricia Hewitt - to explain why one is associated with successful feminist change but the other is not, highlighting how the gendered disposition of the core executive facilitated and constrained gendered policy outcomes.

Harriet Harman, Secretary of State for Social Security and Minister for Women from 1997 to 1998 , has been described as a feminist 'pioneer' (Benn, 1999). ${ }^{7}$ She was part of the movement to feminise the Labour party and its policy programmes prior to election in 1997 (Lovecy, 2007; Russell, 2005). In opening the first government debate on the role of women Harman stated: 'we are committed to building and sustaining a new habit of Government that has women's voices and women's interests at its very heart' (Harman, 1998). However she left office after a period of policy turbulence in the DSS, having presided over controversial cuts to lone-parent benefit (predominantly paid to women). Patricia Hewitt, too, was a committed feminist activist who had campaigned since the 1970s on work-life balance issues (Hewitt, 1993). As Secretary of State for Trade and Industry and Minister for Women 2001-5 she is associated with significant reforms in this area, notably the extension of maternity and paternity leave and pay and the introduction of the right to request flexible employment.

The contrasting experience of these two feminist actors is related firstly to the resources and institutional capacity they could bring to bear to realise policy aims. Harman became Secretary of State for Social Security in 1997 and Frank Field was appointed her deputy to 'think the unthinkable' on welfare reform. As a former chair of the Social Security Select Committee in opposition, Field was deemed a social security policy expert, creating a split authority in the DSS and undermining Harman's ministerial legitimacy. At the same time Harman was appointed the first Minister of Women, assisted by Joan Ruddock, an unpaid junior minister (Benn, 2000). As a Labour minister at the time commented, 'being unpaid gave a signal of the relative unimportance of the role and [Harman's] special advisers had little credibility with civil servants' (interview, 2008). Shortly after the appointment of the Minister for Women, a Women's Unit was established, also located in the DSS, absorbing some staff for the sex equality branch of the Department for Education and Employment (Squires and Wickham-Jones, 2002, p. 65). The Women's Unit was initially small and not well connected within government or, significantly, to the Treasury processes for overseeing spending targets (Himmelweit, 2005; Squires and Wickham-Jones, 2004, p. 83). Initially overwhelmed by dealing with correspondence and parliamentary questions, the Unit had no opportunity to influence policy development (Veitch, 2005).

Harman headed the huge DSS but the informational and organisational resources there did not help her deal with her Women's Minister brief. Harman's civil servants were aware of her interest and commitment to her role as women's minister. The planned closure of a DSS crèche had been drawn to her attention and halted because of the clash with her championing the national childcare strategy. But her focus on gender issues was described as 'Harriet's obsession' and civil servants thought 'there were more important issues than these things that Harriet was worrying about' (interview with senior Benefits Agency 
official, 1999). Most significantly, there was huge pressure from her civil servants to stick to the Conservatives' spending pledge and to accept the cut in lone-parent benefit this implied (interview with former DSS minister, 2007).

Hewitt, as Secretary of State for Trade and Industry and Cabinet Minister for Women had a dual mandate which made her resource rich to advance policy in the area of work-life balance. The move of the Women and Equality Unit (WEU) to the DTI made it possible to strengthen the women's agenda and to align it with that of the DTI. Being Secretary of State for DTI and Minister for Women and having a group of officials in the WEU meant that Hewitt had an extra position in government and could 'reach out and think very clearly about how to move forward on the equality agenda' (interview with minister, 2007). This view is reinforced by a former special adviser to Hewitt: 'being given the agenda as Minister for Women with DTI was an important factor [in achieving policy change] because suddenly Patricia was there with the machinery of government that had the capacity to put these policies together ... so it becomes about productivity as well as about women' (interview, 2007). An adviser argued that policy change 'would have happened without the WEU, but we got it more cemented because of them' (interview, 2007).

The second difference between these feminist ministers' capacity to bring about policy change relates to the operation of the external and internal networks and informal relationships crucial to the policy-making process. During Harman's first year in office the establishment of the Women's Unit brought several committed feminist policy campaigners from the IPPR and Fawcett Society into government. However, the policy networks that later became established around gender policy issues had not yet had a chance to develop. The Women's Budget Group, for example, was just developing its relationships with the Treasury (Himmelweit, 2005, p. 111). The trade unions and poverty pressure groups, New Labour's allies during opposition, were lobbying hard against the cuts to lone-parent benefits (interview with former Labour minister, 2007). The internal networks within the core executive were also not established or powerful. For example, the fledgling task network of civil servants responsible for gender mainstreaming across departments was 'moribund' and only just beginning to reactivate (Veitch, 2005).

By 2001 Hewitt had excellent network relationships both with the external policy community and internally with the Treasury, Number 10 and the DTI. Hewitt worked painstakingly to gain support from stakeholder and lobby groups. Her approach was to bring together all stakeholder groups to foster long-term support for the policy agenda, engendering a long-term cultural shift in work-life balance issues. At the DTI, Hewitt had access to established business networks which had to listen to her gender agenda in return for her attention to their lobby interests (interview with former senior DTI official, 2008). Representatives from the Trade Unions Congress (TUC) and women and equality groups found Hewitt and her team receptive to their lobbying and Hewitt instigated a quarterly meeting with the TUC women's committee (interview with TUC official, 2007). Internally Hewitt's approach was to build strong support with her own department as well as a broad consensus on policy issues across government. She built a strong team of officials drawn from the DTI and the WEU to work on the policy proposals and was able to push forward 
the reforms despite some resistance to the agenda, with 'some officials ... saying there are many more important issues than this, and Patricia ... arguing that there isn't' (interview with former special adviser, 2007).

In terms of tactics for achieving policy change there was little space for Harman to manoeuvre. Crucially Harman had problematic relationships within the DSS with her deputy and civil servants. According to a former minister at the centre of government, policy discussions with the Treasury were said to be 'defensive, a wholly one way relationship'. While Harman was having discussions with the Treasury, Field would talk directly to Number 10, leading to a 'dysfunction in the network and split authority' (interview, 2008). According to a Labour frontbencher who had dealings with the DSS at the time, there was so much policy conflict in the DSS that there was 'no space for policy development' (interview, 2008).

Tactically, Hewitt adopted a collaborative and consensual approach as well as being 'persistent and results oriented' (interview with senior DTI official, 2008). She sustained alliances with other female ministers based on years of campaigning in the Labour party. A feminist minister recalls how Hewitt 'used to have regular lunches with other women ministers to talk about these issues' (interview, 2007). She worked hard to gain support from Number 10 and the Treasury using her alliances and 'persistent campaigning' to persuade Blair and Brown of the importance of gender in work-life balance issues (interview with minister, 2007). Feminist policy advisers such as Carey Oppenheim in Number 10 and Maeve Sherlock and Ed Miliband in the Treasury were key to helping this agenda along the way (interviews in DTI, 2007).

Both Harman and Hewitt were policy actors committed to feminist policy change. The constraints faced by Harman were in large part a consequence of the gendered disposition of the core executive inherited in 1997: she had poorer resources and her access to policy, process and informal networks was limited. As one member of Labour's front bench with dealings with the DSS commented, 'the women's brief was ill defined, and [Harman] was pressured into managing budget difficulties and so other issues were put on the back burner ... the opportunity for innovation and change was quickly limited' (interview, 2007). Despite developing alternative gendered policies for lone parents which ultimately 'rectified' the cuts in lone-parent benefit, 'Harriet's credibility took a battering' (interview, 2007). Hewitt benefited from stronger resources enhancing her institutional capability, and by being far more integrated into the internal and external networks. Her ability to drive through policy change is attributed in part to the fact that she worked hard with policy networks - both internal and external - to build supportive coalitions for change.

Our case shows that gendered policy change in mainstream policy areas is possible. It requires an actor committed to gendered policy change to gain access to the core executive and to operate in a power and resources rich position. However, this is not enough to guarantee change. Committed feminist ministers need to work hard in the gendered institution to negotiate the gendered networks, relationships and rules that characterise the core executive. A failure to do so is likely to lead to no policy change. Our case also re-emphasises the point that the core executive is a dynamic rather than a static organisa- 
tion. Efforts during the tenure of New Labour to alter the core executive's gendered disposition made it progressively easier for committed feminist actors to access or create networks and to deploy their tactics successfully.

\section{Conclusion: Gender, Power and Change in the UK Core Executive}

Our research on gender, power and change in the UK core executive demonstrates that the mechanisms of power distribution in the institution - we highlight recruitment, resources, relationships and rules - have a disposition towards the gender that has traditionally dominated it. The gendered disposition of the core executive both facilitates and constrains the capacity of committed feminist policy actors - ministers and bureaucrats - to gender policy outcomes. Empirically we focus on the capacity of two feminist ministers to realise their desire for policy outcomes favouring gender equality. We conclude that their relative successes are not explained by their skill as politicians or the strength of their commitment to feminising policy, but by the gendered institutional venue in which they operated. Crucially, we stress that the situation is a dynamic one. The interaction of committed feminist actors with the gendered institutions described here since 1997 has altered the gendered disposition of this venue and thus the opportunities and constraints for policy making. As such, our article makes a series of substantial contributions to the mainstream scholarship on the core executive, the gender and politics literature on the substantive representation of women and new and feminist institutionalist scholarship. In concluding, we highlight these contributions and their implications for future research agendas.

By exposing the gendered disposition of recruitment, resources, relationships and rules of the UK core executive we provide an analysis of one dimension of the unequal power dynamics of the core executive that structures political opportunities in Britain. Our analysis provides insights for mainstream core executive scholars into the allocation of power in this key institution, both generally and in gender terms. Comparative research is needed to see whether the same disposition exists in other Westminster-style democracies. In addition, our framework provides core executive scholars with an analytical framework for examining the impact of structural inequalities on other excluded groups, for example political actors from minority ethnic communities.

Our research contributes to gender and politics scholarship that seeks to identify the theoretical and empirical links between the presence of feminists in politics and substantive policy outcomes for women. Our argument is that to understand whether, when and how gender policy change can be achieved it is crucial to identify first the appropriate institutional venue for policy change and to assess the resources of and constraints on feminist actors operating in that site. In the context of the UK - and other Westminster-style democracies - the focus should be on the core executive rather than parliament or women's policy agencies in isolation. By honing in on the core executive as the site of policy-making power in the UK context and identifying the gendered disposition of this institutional site, we are able to demonstrate empirically the opportunities for and constraints on achieving the substantive representation of women. More 'thick' empirical accounts of gendered policy change in the core executive are required to test further our theoretical claim. 
We demonstrate that the gendered disposition and power dynamics of the UK core executive are not static. Rather, the interaction of institutions and feminist actors has over the lifetime of New Labour governments gradually improved the gendered disposition of this institution. This is an important contribution to the new institutionalist literature on the triggers for institutional change. At the same time, it raises an empirical question about whether this 'en-gendering' of the core executive's disposition is institutionally embedded, or vulnerable to retrenchment as has been the case with women's policy agencies.

Finally, we also make an important empirical contribution to the nascent feminist institutionalist scholarship by highlighting the extent to which institutions such as the core executive are gendered. We demonstrate clearly how the presence and experience of feminist actors in institutions such as the core executive relate to other institutions that have similar dispositions. Our research confirms that institutions are not stand-alone entities but are horizontally and vertically integrated and mutually reinforcing. Future research on political institutions should do more to understand this overlapping and interlinkage of public and private institutional configurations.

(Accepted: 16 June 2009)

\section{About the Authors}

Claire Annesley is Senior Lecturer in Politics in the School of Social Sciences, University of Manchester, and convenor of the Gender Research Network. She has published on gender and welfare policy reform in the Journal of European Social Policy, Parliamentary Affairs and Government and Opposition. She is co-editor (with Francesca Gains and Kirstein Rummery) of Women and New Labour: Engendering Politics and Policy (Policy Press, 2007) and editor of Engendering Politics and Policy, a themed edition of the journal Policy and Politics (2010). See http:// www.socialsciences.manchester.ac.uk/disciplines/politics/about/staff/annesley/

Claire Annesley, Politics, School of Social Sciences, University of Manchester, Manchester M13 9PL, UK; email: Claire.Annesley@Manchester.ac.uk

Francesca Gains is Senior Lecturer in Public Policy in the School of Social Sciences, University of Manchester, where she is a member of the Gender Research Network. She co-edited (with Claire Annesley and Kirstein Rummery) Women and New Labour: Engendering Politics and Policy (Policy Press, 2007) and has published on the core executive and policy making in the Journal of Public Policy, Public Administration, Public Policy and Administration and Parliamentary Affairs. For further details of publications and research projects see www.socialsciences.manchester.ac.uk/ disciplines/politics/about/staff/gains/

Francesca Gains, Politics, School of Social Sciences, University of Manchester, Manchester M13 9PL, UK; email: Francesca.Gains@Manchester.ac.uk

\section{Notes}

For comments and suggestions the authors thank Martin Burch, three anonymous referees and participants at the PSA 'Gender, Equality and Politics' conference, University of Surrey, 16 February 2008 and the 'Gender, Politics and Institutions: Towards a Feminist Institutionalism?’ workshop at the ECPR Joint Sessions, University of Rennes, 11-16 April 2008.

1 Interview data derive predominantly from two ESRC-funded projects: 'Whitehall Project' L124251023 'The Changing Role of Central Government Departments'; Francesca Gains thanks the grant holder Martin Smith and the officials and politicians interviewed for their assistance; and 'Gendering Welfare Reform in Adult Worker Model Welfare States: The UK' RES-00022-1615; the grant holder Claire Annesley thanks the ministers, politicians, officials, special advisers and lobbyists interviewed.

2 In the UK, ministers can also be recruited from the House of Lords (Eason, 2009).

3 Joined at one point by Baroness Young from the Lords.

4 Margaret Beckett; Clare Short; Mo Mowlem; and Harriet Harman. 
5 beta.civilservice.gov.uk/about/leads/governance/permanent-secretaries.aspx [accessed 3 April 2009].

6 www.equalities.gov.uk/about/index.htm

7 Since 2007 Leader of the House of Commons, Minister for Women and Equality and Deputy Leader of the Labour party.

\section{References}

Aitkenhead, D. (2005) 'Behind Closed Doors', The Guardian, 12 May. Available from: http://www.guardian.co.uk/politics/ 2005/may/12/women.labour [Accessed 24 July 2006].

Annesley, C. (2007) 'Women’s Political Agency and Welfare Reform', Parliamentary Affairs, 60 (4), $452-66$.

Annesley, C. (2010) 'Gender, Politics and Policy Change: The Case of Welfare Reform under New Labour', Government and Opposition, 45 (1), 50-72.

Annesley, C. and Gains, F. (2007) 'Feminising Politics and Policy', in C. Annesley, F. Gains and K. Rummery (eds), Women and New Labour. Bristol: Policy Press, pp. 3-26.

Annesley, C., Gains, F. and Rummery, K. (eds) (2007) Women and New Labour: Engendering Politics and Policy? Bristol: Policy Press.

Ashley, J. (2004) 'Better Clare Short than the Politics of Yah-and-Boo', The Guardian, 4 March. Available from: http:// www.guardian.co.uk/politics/2004/mar/04/women.gender [Accessed 24 July 2006].

Ashley, J. (2008) 'Clarkson for Prime Minister?', The Guardian, 31 March. Available from: http://www.guardian.co.uk/ commentisfree/2008/mar/31/women.gender [Accessed 10 June 2009].

BBC (2007) 'Shape Up Sir Humphrey', Part 3, Radio 4, 27 March.

Bedell, G. (2002) 'The Trials of Tessa', The Observer, 19 May. Available from: http://www.guardian.co.uk/politics/2002/ may/19/interviews.uk [Accessed 24 July 2006].

Benn, M. (1999) 'The Reinvention of Harriet', The Guardian, 29 June. Available from: http://www.guardian.co.uk/ politics/1999/jun/29/welfarereform.society [Accessed 24 July 2006].

Benn, M. (2000) 'A Short March through the Institutions', in A. Coote (ed.), New Gender Agenda. London: IPPR, pp. 40-8.

Bevir, M. and Rhodes, R. A. W. (2006a) Governance Stories. London: Routledge.

Bevir, M. and Rhodes, R. A. W. (2006b) 'Prime Ministers, Presidentialism and Westminster Smokescreens', Political Studies, $54(4), 671-90$

Bradberry, G. (1998) 'Blair's Laddish Culture', The Times, 24 November, p. 17.

Bright, M. (2005) 'Labour's Trouble with Women', The Observer, 20 February. Available from: http://observer.guardian.co.uk/ focus/story/0,,1418531,00.html [Accessed 16 June 2005].

Bunting, M. (2009) 'When Women Can't Win', The Guardian, 5 June. Available from: http://www.guardian.co.uk/ politics/2009/jun/05/mps-expenses-women-politicians-westminster [Accessed 10 June 2009].

Burch, M. and Holliday, I. (1996) The British Cabinet System. London: Prentice-Hall.

Burch, M. and Holliday, I. (2004) 'The Blair Government and the Core Executive', Government and Opposition, 39 (1), 1-21.

Castle, B. (1993) Fighting All the Way. London: Macmillan.

Celis, K., Childs, S., Kantola, J. and Krook, M. (2008) 'Rethinking Women's Substantive Representation', Representation, 44 (2), 99-110.

Chappell, L. (2004) Gendering Government. Vancouver: University of British Columbia Press.

Chappell, L. (2006) 'Comparing Political Institutions', Gender and Politics, 2 (2), 223-34.

Childs, S. (2004) New Labour's Women. London: Routledge.

Childs, C. and Krook, M. L. (2008) 'Critical Mass Theory and Women's Political Representation', Political Studies, 56 (3), 725-37.

Childs, S. and Withey, J. (2004) 'Women Representatives Acting for Women: Sex and the Signing of Early Day Motions in the 1997 British Parliament', Political Studies, 52 (3), 552-64.

Civil Service Statistics (2008) Available from http://www.civilservice.gov.uk/about/working/diversity/previous-targets.aspx [Accessed 2 February 2010].

Coote, A. (ed.) (2000) New Gender Agenda. London: IPPR. 
Curtin, J. (2008) 'Women, Political Leadership and Substantive Representation of Women', Parliamentary Affairs, 61 (3), $490-504$

Curtin, J. (2009) 'Charting a Political Career'. Paper presented to ECPR Politics and Gender Conference, Queens University, Belfast, 21-3 January.

Day, E. (2009) 'The day I Interviewed a Feisty Caroline Flint for that Photoshoot', The Observer, 7 June. Available from: http://www.guardian.co.uk/politics/2009/jun/07/caroline-flint-photoshoot-women-cabinet [Accessed 10 June 2009].

Deakin, N. and Parry, R. (2000) The Treasury and Social Policy. Basingstoke: Macmillan.

Dunleavy, P. and Rhodes, R. A. W. (1995) Prime Minister, Cabinet and Core Executive. Basingstoke: Palgrave Macmillan.

Durose, C. and Gains, F. (2007) 'Engendering the Machinery of Governance', in C. Annesley, F. Gains and K. Rummery (eds), Women and New Labour. Bristol: Policy Press, pp. 93-116.

Eason, C. (2009) 'Women Peers and Political Appointment', Parliamentary Affairs, 62 (3), 399-417.

Flinders, M. (2002) 'Governance in Whitehall', Public Administration, 80 (1), 51-75.

Foster, C. D. (2001) 'The Civil Service under Stress', Public Administration, 79 (3), 725-50.

Gains, F. (1999) 'Implementing Privatisation Policies in Next Steps Agencies', Public Administration, 77 (4), $713-30$.

Gains, F. (2004) 'Hardware, Software or Network Connection?', Public Administration, 82 (3), 547-66.

Harman, H. (1998) Women (Government Priorities) Debate, Hansard, 27 February, col. 608. Available from: http:// www.parliament.gov.uk [Accessed 24 July 2006.]

Harman, H. (2004) 'Why the Lobby Needs Women', The Independent, 27 September. Available from: http://www. independent.co.uk/news/media/why-the-lobby-needs-women-547818.html [Accessed 24 July 2006].

Hay, C. and Richards, D. (2000) 'The Tangled Webs of Westminster and Whitehall', Public Administration, 78 (1), 1-28.

Heclo, H. and Wildavsky, A. (1979) The Private Government of Public Money. London: Macmillan.

Hennessy, P. (1989) Whitehall. London: Secker and Warburg.

Hernes, H. M. (1987) Welfare State and Women Power. Oslo: Norwegian University Press.

Hewitt, P. (1993) About Time. London: Rivers Oram Press.

Hill, L. and Chappell, L. (2006) 'Introduction', in L. Chappell and L. Hill (eds), The Politics of Women's Interests. London: Routledge, pp. 1-4.

Himmelweit, S. (2005) 'Making Policy-Makers More Gender Aware', Journal of Women, Politics and Policy, 27 (12), $109-21$.

Hogg, S. and Hill, J. (1996) Too Close to Call. London: Time Warner Paperbacks.

Jalalzai, F. (2008) 'Women Rule', Politics and Gender, 4 (3), 205-31.

James, O. (2004) 'The UK Core Executive's Use of Public Service Agreements as a Tool of Governance', Public Administration, $82(2), 397-419$.

Kaufman, G. (1997) How to Be a Minister, second edition. London: Faber and Faber.

Kenny, M. (2007) 'Gender, Institutions and Power', Politics, 27 (2), 91-100.

Lovecy, J. (2007) ‘Framing Claims for Women', in C. Annesley, F. Gains and K. Rummery (eds), Women and New Labour. Bristol: Policy Press, pp. 63-92.

Lovenduski, J. (2005) Feminizing Politics. Cambridge: Polity.

McBride Stetson, D. and Mazur, A. (eds) (1995) Comparative State Feminism. London: Sage.

Mackay, F. (2006) 'Descriptive and Substantive Representation in New Parliamentary Spaces', in M. Sawer, M. Tremblay and L. Trimble (eds), Representing Women in Parliament. London: Routledge, pp. 171-87.

Mackay, F. (2008) “ “Thick” Conceptions of Substantive Representation', Representation, 44 (2), 125-39.

Marsh, D. and Rhodes, R.A.W. (1992) Policy Networks in British Government. Oxford: Clarendon Press.

Marsh, D., Richards, D. and Smith, M. J. (2001) Changing Patterns of Governance in the UK. Basingstoke: Palgrave Macmillan.

Marsh, D., Richards, D. and Smith, M. J. (2003) 'Unequal Plurality: Towards an Asymmetric Power Model of British Politics', Government and Opposition, 38 (3), 306-32.

Mazur, A. (2002) Theorising Feminist Policy. Oxford: Oxford University Press.

Mowlem, M. (2002) Momentum. London: Hodder and Stoughton.

Mushaben, J. (2005) 'Girl Power, Mainstreaming and Critical Mass', Journal of Women, Politics and Policy, 27 (1/2), 135-61. 
Norris, P. and Lovenduski, J. (1994) Political Recruitment. Cambridge: Cambridge University Press.

O’Donnell, G. (2006) 'The Modern Civil Service', Speech to The Guardian Public Services Summit, St Albans, Hertfordshire, 27 January.

Outshoorn, J. and Kantola, J. (eds) (2007) Changing State Feminism. Basingstoke: Macmillan.

Perrigo, S. (1995) 'Gender Struggles in the British Labour Party from 1970 to 1995', Party Politics, 1 (3), 407-37.

Peters, G., Rhodes, R. A.W. and Wright, V. (eds) (2000) Administering the Summit. Basingstoke: Palgrave Macmillan.

Platell, A. (2001) 'Ahead of the Game', The Guardian, 12 November. Available from: http://www.guardian.co.uk/world/ 2001/nov/12/gender.uk [Accessed 24 July 2006].

Public Administration Committee (2007) HC305-I Minutes of Evidence, the Work of the Cabinet Office, 6 February. London: Stationery Office.

Public Administration Committee (2009) HC504-I Q35 Minutes of Evidence, Special Advisors, 7 May. Available from: http://www.publications.parliament.uk/pa/cm200809/cmselect/cmpubadm/uc504-i/uc50401.htm [Accessed 10 June 2009.].

Rhodes, R. A. W. (1995) Understanding Governance. Milton Keynes: Open University Press.

Richards, D. (2007) New Labour and the Civil Service. Basingstoke: Palgrave.

Russell, M. (2005) Building New Labour. London: Palgrave.

Short, C. (2004) An Honourable Deception? London: Free Press.

Sieghart, M. (2001) The Magnificent Seven', The Times, 15 October.

Smith, M. J. (1993) Pressure, Power and Policy: State Autonomy and Policy Networks in Britain and the United States, Hemel Hempstead: Harvester Wheatsheaf; Pittsburgh: University of Pittsburgh Press.

Smith, M. J. (1999) The Core Executive in Britain. London: Macmillan.

Smith, M. J., Marsh, D. and Richards, D. (1993) 'Central Government Departments and the Policy Process', Public Administration, 71 (4), 491-518.

Squires, J. and Wickham-Jones, M. (2002) 'Mainstreaming in Westminster and Whitehall', Parliamentary Affairs, 55 (1), 57-70.

Squires, J. and Wickham-Jones, M. (2004) 'New Labour, Gender Mainstreaming and the Women and Equality Unit', British Journal of Politics E International Relations, 6 (1), 81-98.

True, J. (2003) 'Mainstreaming Gender in Global Public Policy', International Feminist Journal of Politics, 5 (3), $368-96$.

Veitch, J. (2005) 'Looking at Gender Mainstreaming in the UK Government', International Feminist Journal of Politics, 7 (4), 600-6.

Vickers, J. (2006) 'The Problem with Interests', in L. Chappell and L. Hill (eds), The Politics of Women's Interests. London: Routledge, pp. 5-38.

Watson, S. (1994) 'Producing the Right Sort of Chap', Policy and Politics, 22 (3), 211-22.

Watt, N. (2009) 'Caroline Flint Accuses Gordon Brown of Excluding Women from his Inner Circle', The Guardian, 5 June. Available from: http://www.guardian.co.uk/global/2009/jun/05/caroline-flint-resignation [Accessed 10 June 2009 ].

Waylen, G. (2007) Engendering Transitions. Oxford: Oxford University Press.

Women and Equality Unit (2005) Delivering on Gender Equality. London: DTI. 